\title{
FACTORS THAT CONTRIBUTE TO THE SATISFACTION OF STUDENT IN THE MEDICAL RESIDENCY PROGRAM
}

\author{
Vitriana Biben, Dian Marta Sari, Farida Arisanti, Sunaryo B Sastradimadja \\ Physical Medicine and Rehabilitation Department, Hasan Sadikin General Hospital, Faculty of Medicine \\ Universitas Padjadjaran Bandung, Indonesia
}

\begin{abstract}
Background: A high demand of physiatrist should be supported by quality assurance in education system of Physical Medicine \& Rehabilitation (PMR) residency program, that could be done by evaluating satisfaction of its service users. This study was conducted to find the dimensions of service quality that influences the students satisfaction.

Methods: A cross-sectional study with fifty subjects using total sampling technique was conducted. Service quality was evaluated using ServQual questionnaire consisted of five dimensions: 'tangible', 'reliability', 'responsiveness', 'assurance' and 'empathy'. Statistical analysis consisted of bivariate analysis followed by a multivariate analysis was performed to determine the most significant dimension associated with student satisfaction which was measured using Likert scale.

Results: Bivariate analysis revealed that all dimensions had significant association with satisfaction ( $\mathrm{p}$ value $<$ 0,05 ) except for 'tangible' $(p$ value $=0,060$ ). Further multivariate analysis resulted in 'reliability' dimension as the most significant dimension associated with satisfaction ( $\mathrm{p}$ value $=0,005$; Adjusted $\mathrm{OR}=142,67$; CI 95\% $=15,460-1316,587$ ).

Conclusion: Reliability is the most significant dimension associated with student satisfaction. Improvement of this dimension, followed by other significant dimensions would lead to satisfaction of the students.
\end{abstract}

Keywords: evaluation study; physical medicine and rehabilitation; satisfaction; service quality

\begin{abstract}
ABSTRAK
Latar belakang: Tingginya kebutuhan akan dokter Spesialis Kedokteran Fisik dan Rehabilitasi harus diikuti dengan terjaminnya mutu / kualitas sistem pendidikan dalam program residensi Ilmu Kedokteran Fisik dan Rehabilitasi (IKFR). Penjaminan kualitas dapat dilakukan dengan cara mengevaluasi kepuasan mahasiswa selaku pengguna layanan sistem pendidikan. Tujuan penelitian ini adalah untuk menemukan dimensi kualitas pelayanan (service quality) yang berpengaruh terhadap kepuasan para mahasiswa.

Metode: Penelitian ini dilakukan menggunakan desain penelitian potong lintang dengan lima puluh subjek penelitian yang diambil menggunakan teknik total sampling. Service quality diukur menggunakan kuesioner ServQual yang terdiri dari lima dimensi: 'tangible', 'reliability', 'responsiveness', 'assurance' and 'empathy'. Perhitungan statistik dilakukan untuk menemukan hubungan dimensi service quality terhadap kepuasan mahasiswa yang diukur menggunakan skala Likert, serta mencari dimensi mana yang memiliki pengaruh paling kuat terhadap kepuasan mahasiswa.

Hasil: Analisis bivariat menunjukkan bahwa seluruh dimensi kecuali 'tangible' memiliki hubungan signifikan dengan kepuasan (nilai p 'reliability', 'responsiveness', 'assurance' =0,0001; 'empathy'=0,003; 'tangible' =0,060). Analisi multivariat selanjutnya menemukan bahwa dimensi 'reliability' merupakan dimensi yang paling berpengaruh terhadap kepuasan mahasiswa (nilai p =0,005; Adjusted OR = 142,67; IK 95\% = 15,460-1316,587).

Kesimpulan: 'Reliability' adalah dimensi yang memiliki pengaruh paling kuat terhadap kepuasan mahasiswa. Perbaikan pada dimensi ini serta dimensi lainnya yang memiliki pengaruh signifikan diharapkan dapat membawa pengaruh terhadap kepuasan mahasiswa akan pelayanan dalam sistem pendidikan.
\end{abstract}

Kata kunci: evaluasi kepuasan, prodi Ilmu Kedokteran Fisik dan Rehabilitasi, service quality, sistem pendidikan kedokteran

contact: dian.marta@unpad.ac.id 


\section{INTRODUCTION}

Residency training is a unique specialty training medical education. The unique specialty training resident physicians go through and the way that is organized within the system of patient care can be a challenge of its education. Ensuring a highquality educational experience encompasses many characteristics of residency program including the number of faculty and trainees, location, medical setting (educational environment), topics (curriculum), time, and techniques that create a challenge. Yet, throughout this challenge of educational process, the residents and faculty should maintain optimal patient care.,

To maintain and improve education services to ensuring a high-quality educational experience to assure good quality of specialists that will be graduate from medical university as an outcome, an evaluation feedback is needed to be done continuously. It was very important to consider because of increasing demand of medical specialist in Indonesia should not sacrifice the quality of its education. ${ }^{3}$ Evaluation is important for maintaining and increasing quality of a product (which is skill of the students and graduates), also the education system itself which is a product of university with the students as its consuments. ${ }^{4 \cdot 7}$

One of the aspects in medical education evaluation is the outcome of education itself which is involve quality of service that provided by the institution to the student. Parasuraman and Zeithamal stated that one of the methods used for measuring the quality of service is the SERVQUAL method, that is described as "the most complete attempt to conceptualize and measure service quality" and a standard tool including in healthcare and medical education evaluation. ${ }^{8}$ The SERVQUAL method is evaluating five dimensions of service quality consist of tangible (educational infrastructure), reliability (capability of lecturer and academic staffs), responsiveness (ability to react quickly), assurance (guarantee in educational process) and empathy (understanding of student needs).9 This method is used to measure the quality of service, where the association between expectation and perception of the customer can be measured. The approach can estimate the gap between expectations and perception of customers, in this case was student, concerning the quality of services they receive. ${ }^{9}$ This evaluation is important because it has been associated with later professional attitudes, career commitment and retention..$^{10}$

Physical Medicine and Rehabilitation (PMR) residency program in Faculty of Medicine, University of Padjadjaran has been established since 2008.,11 PMR residency program of Universitas Padjadjaran has been producing 9 graduates until 2014 which have passed two National Examination for PMR Specialist, with the passing rate of $100 \%$ and cumulative Grade Point Average (cGPA) ranging from $2,75-3,59 .{ }^{11}$ Increasing of life expectancy and diseases that made a disabilities nowadays make the number of Physiatrist (PMR Specialist) required is also increasing. Therefore, we need continual evaluation to improve and increasing quality of the graduates.

It is clear that students' satisfaction in an index for evaluating medical education, but there are few researches measuring this factor. ${ }^{10,12}$ To achieve a good outcome of the educational process and improving quality of medical specialist education, this study was to find out the association between service quality of education system in PM\& $R$ residency program and satisfactory level of the service users (students $\&$ graduates).

\section{METHOD}

This study was conducted as an observational, analytical study using a cross-sectional research design. Sample was taken using the total-sampling technique. From the total of 50 subjects, half of them were students and the rest were graduates. This study was conducted in PM\& R department of Universitas Padjadjaran, started from April 2014 until October 2014.

Service quality was evaluated using servqual method. The five dimensions of service quality consist of Tangible, Reliability, Responsiveness, Assurance and Empathy. ${ }^{9}$ Operational definition of the variables were listed in Table 1 . Satisfactory level of students and graduates was presented in likert scale $(1=$ not satisfied, $5=$ highly satisfied). Data was collected and compiled from a questionnaire that was already validated through preliminary study. 
The independent variable in this study consisted of 5 dimensions of service quality (X1-5), while the dependent variable $(\mathrm{Y})$ was satisfactory level of service users (students \& graduates).

Table 1. Operational Definition of the Variables ${ }^{16}$

\begin{tabular}{|c|c|c|c|}
\hline Variable & $\begin{array}{l}\text { Operational } \\
\text { Definition }\end{array}$ & Evaluated Aspects & $\begin{array}{c}\text { Scale of } \\
\text { measurements }\end{array}$ \\
\hline $\begin{array}{l}\text { Tangible } \\
\text { (X1) }\end{array}$ & $\begin{array}{l}\text { Physical resources, } \\
\text { infrastructure, } \\
\text { materials needed to } \\
\text { provide service }\end{array}$ & $\begin{array}{l}\text { Lecture room } \\
\text { Learning media in lecture room } \\
\text { Literatures } \\
\text { Room for skills lab } \\
\text { Clinic } \\
\text { Media for scientific presentation } \\
\text { Student placement in other health center (for learning } \\
\text { purpose) } \\
\text { Tutorial topics to enhance clinical skills }\end{array}$ & Ordinal \\
\hline
\end{tabular}

Reliability Ability to deliver

(X2)

Responsive- Reactions or ness (X3) responsivity towards the needs of students when it is needed

Assurance Ability to conceive (X4) the service proficiently, accurately, and consistently guarantee and trust
Capability of the teachers to explain study topics and

Ordinal maintain dynamic discussion during class.

Capability of the teachers to properly guide the students in order to uunderstand the topics, balancing clinical reasoning with the practice of evidence-based medicine during class.

On-time arrival of the teachers

Capability of the teachers to understand and comprehend the discussion topics

Explanation from the lecturers related to the clinical pathway informations

Role of the lecturers during personal councelling

Ordinal Starting examination right on time

Starting class right on time

Ability to manage academic problems of the student

Manners of the lecturers when delivering academic service

Ordinal
Management of problems/complaints of the students

by the teachers staffs

Effectivity of time-management of the teacher staffs

during learning process

Understanding of the teachers ,2

regarding the guideline of academic implementation

applied at PMR department

Clarity and justice without exception regarding

punishment for rule-breaking students

Academic qualification of the teachers as prerequisite for teaching in PMR department 
Empathy Ability to show

(X5) empathy and caring, understand the needs of students
Ability of the lecturers and academic staffs to understand the interests and difficulties

for the students

Monitoring the development of the students by the guardian teacher or councelling teacher Availability of the teacher staffs for helping the students in managing academic problems

Friendly approach of the teachers towards the students Understanding and nurturing (minat) and talents of the students

\begin{tabular}{|c|c|c|c|}
\hline $\begin{array}{l}\text { Satisfactory } \\
\text { level of the } \\
\text { students (Y) }\end{array}$ & $\begin{array}{l}\text { Obtained after } \\
\text { comparing } \\
\text { the result of a } \\
\text { process (in service } \\
\text { delivery) with the } \\
\text { previously expected } \\
\text { expectation. }\end{array}$ & $\begin{array}{l}\text { Satisfied with the quality of the teachers (ability and standard } \\
\text { competency during lecture session / ability to deliver other } \\
\text { knowledge outside the study topics) } \\
\text { Satisfied with the (jasa) of academic staffs (good } \\
\text { communication applied by the teachers and staffs when } \\
\text { delivering service to the students) } \\
\text { Satisfied with the general and academic administration } \\
\text { (clarity of the information, service delivery such as } \\
\text { constructing study planning, scholarship, and other } \\
\text { important documents) } \\
\text { Satisfied with the availabillity of physical resources or } \\
\text { materials (availability of teaching media such as LCD, chairs, } \\
\text { tables, markers, etc) }\end{array}$ & $\begin{array}{l}\text { Ordinal } \\
\text { (Likert scale } \\
1-5 ; \\
1=\text { not satisfied } \\
5=\text { highly } \\
\text { satisfied) }\end{array}$ \\
\hline
\end{tabular}

Collected data was analyzed using bivariate and multivariate analysis using SPSS. Bivariate analysis was conducted to discover the association between the dimensions of service quality and the satisfactory level of the service users. After that, multivariate analysis was conducted to find the dimension with the strongest association with the satisfactory level. Bivariate analysis was conducted using the chi square statistical test, while the multivariate analysis used multiple logistic regression.

\section{RESULTS AND DISCUSSION}

The result of bivariate analysis comparing the dimensions of service quality and satisfactory of service users was presented in Table 2. 'Reliability' dimension showed significant relationship with satisfactory level in this study. Statistical test resulted in the $\mathrm{p}$ of 0,0001 , which was considered to be significant association. From the odds ratio, it can be concluded that good 'reliability' would give a chance of better satisfactory for as much as 151 times more than satisfactory in poor 'reliability' (OR: 151,8; CI:16.618-1386.610). Meanwhile, statistical test of 'responsiveness' dimension also resulted in significant association with the satisfactory level ( $p$ values $=0,0001)$. The odds ratio showed that an increase in 'responsiveness' would give a chance of better satisfactory level as much as 5 times than satisfactory level in poor 'responsiveness' services (OR: 5,2; CI:2.814-9.793).

'Assurance' dimension ( $\mathrm{p}$ value $=0,0001$ ) and 'empathy' ( $p$ value $=0,003$ ) were also found to have significant association with satisfactory level. From the odds ratio, it could be concluded that services with good 'assurance' has a chance for slightly increasing satisfactory for 0,04 times higher than services with poor 'assurance' (OR 0.04 ; CI 0.286 - 0.572). Meanwhile, services with good 'empathy' had a chance for increasing satisfactory 16 times higher than services with poor 'empathy' (OR: 16,7; CI:2.022-138.192).

Moreover, significant association was not found between 'tangible' dimension of service quality and satisfactory level of service user. From the 41 respondents who stated that 'tangible' was matched with their expectation, 22 respondents $(53,7 \%)$ were satisfied. Meanwhile, from 21 respondents who stated that 'tangible' was lacking, 6 respondents were 
Table 2. Bivariate analysis: the dimensions of service quality compared to satisfactory level of service users

\begin{tabular}{|c|c|c|c|c|c|c|c|c|c|}
\hline \multirow[t]{3}{*}{ Dimensions } & & \multicolumn{4}{|c|}{ Satisfactory } & \multirow{2}{*}{\multicolumn{2}{|c|}{ Total }} & \multirow{3}{*}{$\begin{array}{c}\mathrm{P} \\
\text { value }\end{array}$} & \multirow{3}{*}{$\begin{array}{c}\text { Odd } \\
\text { Ratio }\end{array}$} \\
\hline & & \multicolumn{2}{|c|}{ Satisfied } & \multicolumn{2}{|c|}{ Unsatisfied } & & & & \\
\hline & & $\mathbf{N}$ & $\%$ & $\mathbf{N}$ & $\%$ & $\mathbf{N}$ & $\%$ & & \\
\hline \multirow{3}{*}{ Tangible } & Good & 22 & 53.7 & 19 & 46.3 & 41 & 100 & \multirow{3}{*}{0,060} & \multirow{3}{*}{2,895} \\
\hline & Poor & 6 & 28.6 & 15 & 71.4 & 21 & 100 & & \\
\hline & Total & 28 & 45.2 & 34 & 44.8 & 62 & 100 & & \\
\hline \multirow{3}{*}{ Reliability } & Good & 23 & 95.8 & 1 & 4.2 & 24 & 100 & \multirow{3}{*}{0,0001} & \multirow{3}{*}{151,8} \\
\hline & Poor & 5 & 13.2 & 33 & 86.8 & 38 & 100 & & \\
\hline & Total & 28 & 45.2 & 34 & 44.8 & 62 & 100 & & \\
\hline \multirow{3}{*}{ Responsiveness } & Good & 20 & 100 & 0 & 40.4 & 20 & 100 & \multirow{3}{*}{0,0001} & \multirow{3}{*}{5,20} \\
\hline & Poor & 8 & 19 & 34 & 81 & 42 & 100 & & \\
\hline & Total & 28 & 45.2 & 34 & 44.8 & 62 & 100 & & \\
\hline \multirow{3}{*}{ Assurance } & Good & 28 & 59.6 & 19 & 40.4 & 47 & 100 & \multirow{3}{*}{0,0001} & \multirow{3}{*}{0,04} \\
\hline & Poor & 0 & 6.8 & 15 & 93.2 & 15 & 100 & & \\
\hline & Total & 28 & 45.2 & 34 & 44.8 & 62 & 100 & & \\
\hline \multirow{3}{*}{ Empathy } & Good & 27 & 56.3 & 21 & 43.7 & 48 & 100 & \multirow{3}{*}{0,003} & \multirow{3}{*}{16,7} \\
\hline & Poor & 1 & 7.1 & 13 & 82.9 & 14 & 100 & & \\
\hline & Total & 28 & 45.2 & 34 & 44.8 & 62 & 100 & & \\
\hline
\end{tabular}

Table 3. Multivariate analysis results: association between dimensions of service quality and satisfactory level of service users.

\begin{tabular}{|c|c|c|c|c|c|c|}
\hline Model & Variable & Coeff. B & $\mathrm{SE}^{*}(\mathrm{~B})$ & P value & $\begin{array}{c}\text { Adjusted Odds } \\
\text { Ratio }\end{array}$ & $\begin{array}{l}\text { Confidence } \\
\text { Interval 95\% }\end{array}$ \\
\hline \multirow[t]{6}{*}{ Step 1} & Tangible & 2,202 & 1,318 & 0,095 & 9,044 & $0,684-119.660$ \\
\hline & Reliability & 2,760 & 1,423 & 0,005 & 15,79 & $0,971-256.944$ \\
\hline & Responsiveness & 21,264 & 7980,7 & 0,998 & 1,71 & 0,000 \\
\hline & Assurances & 20,486 & 1008,1 & 0,998 & 7,89 & 0,000 \\
\hline & Empathy & $-0,507$ & 2,76 & 0,854 & 0,602 & $0,003-134.884$ \\
\hline & Constanta & $-69,443$ & 18881,75 & 0,997 & 0,000 & \\
\hline \multirow[t]{3}{*}{ Step 2} & Reliability & 4,961 & 0,956 & 0,0005 & 142,67 & $15,460-1316,587$ \\
\hline & Tangible & 0,766 & 0,956 & 0,423 & 2,152 & $0,331-14,002$ \\
\hline & Constanta & $-9,072$ & 2,493 & 0,0005 & 0,0005 & \\
\hline
\end{tabular}

*Standard Error 
satisfied. The result of chi-square test presented a p-value of 0,060 .

The overall result of multivariate analysis conducted to find association between dimensions of service quality and satisfactory level were presented in Table 3. It was found that 'reliability' had the most significant association with the satisfactory level ( $p$ value $=0,005$ ). From the statistical test, it was found that the highest adjusted OR was 142,67. According to this finding, it could be stated that services with poor reliabilty might have a chance of having poor satisfactory level for 142 times higher rather than in a service with good reliability.

Based on the bivariate analysis, it was found that all the dimensions except for 'tangible' dimension was significantly associated with residents' satisfaction. This finding is also similar with previous study conducted by Khan, Ahmed and Nawaz in several universities in Pakistan, which stated that all dimension had significant association with the satisfactory level of the students except for 'tangible'. ${ }^{13}$ Different result was reported within another study conducted by Sujatmiko, Santoso, Soenoko et al towards engineering students at Malang, which found that 'reliability' had no significant influence towards satisfactory level, and 'tangible' dimension, inversely, had the most significant influence towards satisfactory level of the students. It was possible because the ability to provide infrastructures and physical resources is also a concrete form of service and importance thing for engineering students that has to delivered by the service provider. ${ }^{14}$

The dimension of 'responsiveness' showed a significant association in this study, similar with previous study conducted by Çerri in the University of Albania. ${ }^{15}$ A study conducted by Aghamolaei and Zare at the Faculty of Medicine, University of Hormozgan, Iran also found significant association between 'responsiveness' and satisfactory level, and this dimension was found to be the most important factor that influence the quality of education in the University of Hormozgan because of its high gap between expectation and reality compared with another dimensions of service quality. ${ }^{16}$
Table 2 and 3 presented the significant association between 'assurance' and 'empathy', which was in accordance with previous studies conducted by Khan et al, and Cerri that showed there is positive and significant relationship between dimensions of service quality and students' satisfaction (Assurance, Responsiveness Empathy and Reliability) with satisfaction. ${ }^{13,15}$ Based on the multivariate analysis comparing the associations of each five dimensions with the satisfactory level, 'reliability' was found to have the most significant association with satisfactory. The study of Khan, Ahmed and Nawaz in students in public sector university stated a similar finding with this study regarding the 'reliability' as the most significant factor associated with satisfactory level. ${ }^{13}$ Another study conducted on 400 undergraduates from various study program in Thailand also found that reliability was the dimension that satisfied them the most. ${ }^{17}$ Previous studies with different findings were also found, such as study conducted by Hasan in Malaysia which found that 'assurance' and 'empathy' were the most significant factors that influenced the satisfactory level of the Bachelor Degree students from Kuala Lumpur Infrastructure University College (KLiUC) and Kolej Universiti Teknologi dan Pengurusan Malaysia (KUTPM). ${ }^{18}$ Another finding was also found in the study conducted by Tamnge in Faculty of Teachings and Education at the Universitas Muhammadiyah Surabaya which stated that 'tangible', 'reliability', and 'assurance' were the most significant variables that influenced the satisfactory of the students. ${ }^{19}$

The different findings of the most satisfying dimension might be caused by the different type of courses or majors taken by the students in all these studies that influence satisfactory level. ${ }^{20}$ This different type of courses and majors might cause different perceptions and expectations of the students towards education service system. It was shown that in this study, satisfactory level was not significantly influenced by physical resources (tangible factors), but more by intangible factors. This result might be caused by the averted attention more to the quality of process in education system rather than physical infrastructure and media. 
Differences of the generation characteristics of the resident may also influence the differences of the study result. Generational groups tend to share major life experiences and societal events. This common history leads to mutual values, beliefs, attitudes, and behaviors. The generation $\mathrm{X}$ (born 1964-1980) and generation millennial (born 1980-1999) of physician-in-training generally has different values and priorities than their prototypes. Generation X is often described as independent, self-directed, pragmatic and flexible. They are more likely to question authority, to have less commitment to existing institutions and to emphasize time off for family and relationships. ${ }^{21,22}$ Next generation, generation millenial (also known as generation Y) are often described as optimistic, collaborative, team-oriented and techno-savy. They prefer internet resources to textbooks for learning. Millennials are optimistic about their careers, and are more trusting of authority. They tend to want a frequent, personal, focused, and positive feedback from their mentors. They value their relationships with others, effective feedback and a participation in mentoring with information sharing and involvement in creative solutions may be used to allow for more productive mentoring. Mentoring should be developing with a respectful, collegial, and close relationship over time and ensuring that the needs of the mentor are met.23 The role of mentor for them should become reliable, so it may explain why reliability dimension is become the most dimension that influence the satisfaction in the study, refer that samples is all millennials group.

This study only limited population that was residency program of PMR Department in Faculty of Medicine University of Padjadjaran, based on variability major disciplines, this result cannot be generalized. These characteristics represent generalization, and not all constituents of group are having similar characteristics in their views, perception, and attitudes.

\section{CONCLUSION}

From the five dimensions of service quality, four dimensions (reliability, responsiveness, assurance, empathy) had significant association with the satisfactory level of service users. 'Reliability' dimesion had the most significant association compared to another three dimensions of service quality. This results should be considering in evaluation of residency programs especially in mentorship. Mentorship, as a cornerstone of academic medicine is suggested to be more effective or successful if organized with shared goals or experiences. The whole process of education not only considering the tangible factors but also intangible such as improving the capability of teaching of the mentor or teacher. Increasing the capability in skills of transfer of knowledges of mentors are also important thing to increase satisfaction of the students. Succesfull of education should also consider the characteristic of generation that might be change the approach of the process of the education.

\section{REFERENCES}

1. Organization of Resident Representatives. Association of American Medical Colleges. Defining the Key elements of an Optimal Residency Program. May 2001.

2. Atsawarungruangkit A. Relationship of residency program chracteristics with pass rate of the American Board of Internal Medicine certifying exam. 2015. Medical Education Online 20:1.

3. Persatuan Dokter Spesialis Rehabilitasi Medik Indonesia. White Book Kedokteran Fisik dan Rehabilitasi. 1st Edition. Jakarta: PT Batu Merah; 2012.

4. Пavga, L. Quality assurance of higher education interms of the national education performance and competitiveness growth. Economy Transdisciplinarity Cognition. 2013;16:43-48.

5. Aldeman L, Towers S, Bannah S. Student feedback systems in high education: a focused literature review and environmental scan. Quality in Higher education. 2012;18(3):261-80.

6. Tessema MT, Ready K, You WC. Factors affecting college students satisfactions with major curriculum: Evidence from nine years of data. International Journal of Humanities and Social Science. 2012;2(2):34-44.

7. Yarris LM, Brunnet PH, Fu R. Attending and Resident Satisfaction with Feedback in the Emergency Department. Western Journal of Emergency Medicine. 2007;8(3):109. 
8. Bahadori M, Mousavi SM, Sadeghifar J, Haghi M. Reliability and Perfomance of SEVQUAL Survei in Evaluating Quality of Medical Education Services. Internasional Journal of Hospital Research. 2013. 2(1): 39-44. www.ijhr.iums.ac.ir

9. Parasuraman A, Zeithami VA, Berry LL. Servqual: A Multiple-Item Scale for Measuring Consumer Perceptions of Service Quality. Journal of Retailing. 1988;64(1).

10. Ziaee V, Ahmadinejad Z, Morravedji AR. An evaluation on Medical Students' Satisfaction with Clinical Education and its Effective Factors. Med Educ Online [serial online]. 2004;9:8. Available from http://www.med-ed-online.org

11. Evaluasi Diri Program Studi Pendidikan Dokter Spesialis I Ilmu Kedokteran Fisik dan Rehabilitasi Fakultas Kedokteran Universitas Padjadjaran Bandung. Akreditasi Program Studi Dokter Spesialis. Jakarta: LAM-PT KES, 2014.

12. Prytowsky JB, Bordage G. An outcomes research perpective on medical education: the predominance of trainee assessment and satisfaction. Med Edu. 2001; 35(4): 331-6

13. Khan MM, Ahmed I, Nawaz MM. Student's Perspective of Service Quality in Higher Learning Institutions; An evidence Based Approach. International Journal of Business and Social Science. 2011;2(11): 159 .

14. Sujatmiko SP, Soenoko R, Astuti M. Upaya Peningkatan Pelayanan Terhadap Kepuasan Mahasiswa Berdasarkan Hasil Analisis Metode Servqual dan Regresi Liner Berganda (Studi Kasus Jurusan Teknik Mesin Universitas di Malang). Jemis. 2013;1(1).
15. Çerri S. Assessing The Quality Of Higher Education Services Using A Modified Servqual Scale. Annales Universitatis Apulensis Series Oeconomica. 2012;14(2):664.

16. Aghamolaei T, Zare S. Quality gap of educational services in viewpoints of students in Hormozgan University of medical sciences. BMC Med Educ 2008;8(34).

17. Yousapronpaiboon K. SERVQUAL: Measuring higher education service quality in Thailand. Procedia - Social and Behavioral Sciences. 2014; 116: $1088-1095$.

18. Hasan HF. Service Quality and Student Satisfaction: A Case Study at Private Higher Education Institutions. Business Reasearch. 2008:163.

19. Tamnge NR. Regresi logistik biner dalam menentukan pengaruh kualitas pelayanan terhadap kepuasan mahasiswa fakultas keguruan dan ilmu pendidikan universitas muhammadiyah Surabaya. Must. Juni 2016;4(1).

20. Palli JG, Mamilla R. Students opinion of service quality in the field of higher education. Creative Education. 2012;3(4): 430-8

21. Cochran A, Melby S, Neumayer LA. An internetbased survei of factors influencing medical student selection of a general surgery career. The American Journal of Surgery. 189 (2005) 742-746

22. Losyk B. Generation X: What they think and what they plan to do. Public Management. 1997; 79:4-5

23. Mohr NM, Moreno-Walton L, Mills AM, Brunett PH, Promes SB. Generational Influences in Academic Emergency Medicine: Teaching and Learning, Mentoring and Technology (Part I). Acad emerg Med. 2011. 18(2): 190-199 